\title{
Potentials of African Nutmeg (Monodora myristica) as a Flavourant in Cookie Production
}

\author{
Kazeem K. Olatoye ${ }^{a^{*}}$, Omololu O. Fapojuwo ${ }^{\mathrm{a}}$, Joshu A. Olorunshola ${ }^{\mathrm{a}}$, And \\ Julianah O. AYORINDE ${ }^{a}$ \\ ${ }^{\text {a }}$ Department of Food Science and Technology, College of Agriculture, Kwara State University, Malete, P.M.B \\ 1530, Ilorin, Kwara State, Nigeria \\ ${ }^{*}$ Corresponding author \\ luckykaykay@yahoo.com
}

Received: 13 November 2017; Published online: 18 October 2019

\begin{abstract}
African nutmeg, a possible local substitute for a commercial food flavourant, remains largely underutilized in Nigeria. Its application potential in cookie production was investigated in this study. African nutmeg (Monodora myristica) seed flour (ANM) was produced using a standard method. The flour was substituted for vanilla flavour (VFL) in ratio of $0,1,2,3$, and $3.5 \mathrm{~g}$ and functional properties of the flour blends (water absorption capacity (WAC), oil absorption capacity (OAC), and bulk density) were determined, using standard methods. Cookies were developed and characterized chemically, physically (colour) and organoleptically using the AOAC method, a colourimeter and sensory panellists respectively. Data were analysed using ANOVA at $\mathrm{p}<0.05$. Replacement of vanilla with African nutmeg had no significant effect on bulk density $\left(0.62 \mathrm{~g} \mathrm{~cm}^{-3}-0.68 \mathrm{~g} \mathrm{~cm}^{-3}\right)$, but significantly affected WAC (133-142\%) and OAC (147-156 \%) of flour blends. Crude protein (9.44-15.49\%), crude fat (3.17-6.50\%), total ash (2-2.73\%) and crude fibre (0.12-0.23\%) contents of the cookie increased, whilst metabolizable energy (385.33-367 kcal) decreased. There were reductions in $\mathrm{pH}(6.83-6.53)$ and TSS (5.80-1.20). Brown index of the snack increased with addition of nutmeg. Antioxidant indicators (flavonoids, DPPH and phenol) varied among cookie samples. Antinutrients, saponin, tannin and oxalate, were within tolerable limits. All cookie samples were judged acceptable by the panellists, with SLZ being the most acceptable. An acceptable and nutritious snack was produced at $100 \%$ replacement. M. myristica seed could serve as substitute for vanilla in the production of cookies and other related snacks.
\end{abstract}

Keywords: Monodora myristica; Snack; Flavourant; Food additive; Substitution

\section{Introduction}

Snacks are identified as foods eaten at times other than meals and could be mindfully or unmindfully consumed. They include a variety of products and can take different forms, including potato chips and cereal-based snacks (FAO, 2011; Sajilata \& S. Singhal, 2005; Sumargo, 2016). Globally, the impact of snacks is felt daily mostly in big cities, possibly due to convenience driven lifestyles, job demands and dietary habits (Kruger, 2012; Olatoye \& I. Lawal, 2016). Many people earn their livelihood through snack production and marketing (Norfezah, 2013). Quite often, some snacks are perceived to be sugary and their excessive consumption has been attributed to incidence of obesity, diabetes and coeliac diseases (Ajieroh, 2010). These might be connected with the composition of their ingredients.

Among other ingredients, flavourings remain 
indispensable with application of commercial flavourings in snack production being common, as this is meant to improve the taste and entice consumers. Ironically, some of these flavourings are synthetic and unhealthy. However, producing healthy snacks from locally available materials is the current trend and innovative development in the snack food industry. Consequently, it is necessary to explore natural flavourings and spices that may be considered as possible alternatives to synthetic ones (Enwereuzoh et al., 2015). One example of such possible alternatives is M. myristica, commonly known as African nutmeg. It is a perennial edible plant, belonging to the Ananacea family. It is a berry with many seeds grown in the evergreen forests of West Africa (Burubai, Akor, Igoni, \& Puyate, 2007), with almost every part of the tree possessing both economic and medicinal usefulness. Its pod is used as a seasoning spice in Southern and Eastern Nigeria (Aladesanmi, 2007; Essien, Izunwane, Aremu, \& Eka, 1994). The seeds, which are embedded in the white sweet-smelling pulp of the fruit are considered most economically important (Stephen, O., Oboh, \& Eseosa, 2014). The seed powder is used as spices to prepare pepper soup and also used as stimulant to relieve constipation. Currently, the tendency to use the oil extracted from M. myristica and Tetrapleura tetraptera to flavour popcorn has proven to justify the use of the spices as flavourings with good acceptability and no adverse effect (Enwereuzoh et al., 2015). There have been few studies on the use of African nutmeg incorporated into snacks as it is mostly used in seasoning soups and salads. Largely, Nigerian food industries are still relying on the importation of flavourings at the expense of possible local substitutes (Enwereuzoh et al., 2015). Therefore, the objective of this research was to investigate the potential of African nutmeg as a flavouring agent in the production of cookies.

\section{Materials and Methods}

\subsection{Sources of Materials}

The African nutmeg was obtained from Forestry Research Institute of Nigeria (FRIN), Jericho,
Ibadan, Nigeria. The wheat flour, sugar, salt, egg, and vanilla were bought from modern market, Ilorin, Nigeria. The chemicals and reagents used were of analytical grade A and were obtained from Bumlab Nigeria Limited, Ring Road, Ibadan, Nigeria.

\subsection{Production of African nutmeg powder}

The seeds of M. myristica were shelled manually with the use of mortar and pestle and then milled into powder using an electric blender, sieved with a $250 \mu \mathrm{m}$ mesh and bottled in a sterile plastic container prior to use.

\subsection{Cookie production}

The method described by Eneche (1999) was used to prepare cookies with slight modifications. A fluffy mixture of butter and sugar was obtained by manually mixing $125 \mathrm{~g}$ of baking butter with $120 \mathrm{~g}$ of sugar for $5 \mathrm{~min}$. Another mixture of flour $(250 \mathrm{~g})$, salt $(2.5 \mathrm{~g})$ and baking powder $(10 \mathrm{~g})$ was prepared separately and combined with the butter-sugar mixture to get a dough. A measured amount of water $(20 \mathrm{ml})$ was added gradually and the dough mixed continuously until a good textured, firm dough was obtained. The dough was kneaded on a clean flat surface for $4 \mathrm{~min}$ and transferred to a cutting table where a shape maker was pressed over the dough to give the desired shapes. Dough pieces were then transferred into liquid-fat-greased baking trays and baked at $150{ }^{\circ} \mathrm{C}$ for $20 \mathrm{~min}$, cooled and packaged for analysis.

\subsection{African nutmeg-vanilla flavour formulation for cookie}

African nutmeg (ANM) was substituted for vanilla flavour (VFL) in different proportions of $0,1,2,3$, and 3.5 g i.e. $(0,30,60,90$ and $100 \%)$ respectively, to give five (5) samples (Table 1), according to the modified method described by Adeboye, Babajide, Shittu, Omemu, and Oluwatola (2013). 
African nutmeg and vanilla flavour blends $\mid 3$

Table 1: Substitution of African nutmeg for vanilla flavour in cookie production

\begin{tabular}{lll}
\hline Samples & African nutmeg flour $(\mathrm{g})$ & Vanilla flavour $(\mathrm{g})$ \\
\hline KMO & $0.00(0 \%)$ & $3.5(100 \%)$ \\
JLK & $1.00(30 \%)$ & $2.50(70 \%)$ \\
VRU & $2.00(60 \%)$ & $1.50(40 \%)$ \\
PQS & $3.00(90 \%)$ & $0.50(10 \%)$ \\
SLZ & $3.50(100 \%)$ & $0.00(0 \%)$ \\
\hline
\end{tabular}

\subsection{Determination of functional properties of flour blends}

Water absorption capacity (WAC) and oil absorption capacity (OAC) were determined using the method described by Sosulski (1962). For the WAC, $1 \mathrm{~g}$ of the sample was added into 15 $\mathrm{ml}$ of distilled water in a pre-weighed centrifuge tube, while for the OAC, oil with a known density was added to the sample. The tube with its contents was agitated for $2 \mathrm{~min}$ and centrifuged at $4000 \mathrm{rpm}$ for $20 \mathrm{~min}$ on a SorvallGLC-1 centrifuge (Model 06470, USA). The clear supernatant was discarded and the centrifuge tube was weighed with the sediment. The amount of water or oil bound by the sample was determined by difference and expressed as the weight of water bound by $100 \mathrm{~g}$ dry of flour. Bulk density was determined using the method of AOAC (2000). The flour sample $(7 \mathrm{~g})$ was weighed into a $50 \mathrm{ml}$ graduated measuring cylinder. The cylinder was tapped gently against the palm of the hand until a constant volume was obtained, and the bulk density (BD) calculated as shown in equation 1.

$$
\mathrm{BD}=\frac{\text { weight of sample }}{\text { volume of sample after tapping }}
$$

\subsection{Determinations of proximate composition and energy values of cookie samples}

Proximate composition, including crude protein, fat, moisture content, crude fibre, ash and carbohydrate of the cookie samples were carried out using standard methods described by AOAC (1995). The energy value of the cookie was calculated from percentages of major nutrients in kilo- joules per $100 \mathrm{~g}$ and the values were converted to kcal by dividing them by the conversion factor (4.184) (Maclean et al., 2003) as shown in equation 2 .

$$
\mathrm{EV}(\mathrm{kcal})=\frac{\mathrm{Carb} \times 17+\operatorname{Prot} \times 17+\text { Fat } \times 37}{4.184}
$$

Where EV = Energy value and Carb, Prot and Fat are the composition in carbohydrates, proteins and fats

\subsection{Determination of physicochemical properties of cookie samples}

A Fisher pH meter (Model 210, Fisher Scientific) was used to determine the $\mathrm{pH}$ and an Abbe refractometer was used to determine the total soluble solids content (Brix) at $20{ }^{\circ} \mathrm{C}$. The physical colour of the cookies was quantitatively determined with the aid of a hand-held Colour Tec PCM/PSMTM1 colour meter as described by Babajide and Odulate (2015) using a white tile as reference and recording the brightness $\left(\mathrm{L}^{*}\right)$, redness $\left(a^{*}\right)$ and yellowness $\left(b^{*}\right)$ values, Hunter Lab values.

\subsection{Determination of Antioxidant profile of formulated cookie}

\section{Phenol}

Total phenol was determined by the FolinCiocalteu spectrophotometric method (AOAC, 1990). Extraction of total phenol was done by dissolving $200 \mathrm{mg}$ of the sample in $10 \mathrm{ml}$ methanol $(>99 \% \mathrm{w} / \mathrm{w})$. At room temperature, the mixture was shaken well for $30 \mathrm{~min}$ and centrifuged 
at $500 \mathrm{rpm}$ for about $15 \mathrm{~min}$. The extract from each sample $(1 \mathrm{ml})$ was treated with an equal volume of Folin-Ciocalteu reagent together with addition of $2 \% \mathrm{Na}_{2} \mathrm{CO}_{3}$ solution. Standard phenol solution was prepared and diluted to the desired concentration. The standard solution $(1 \mathrm{ml})$ was treated with Folin-Ciocalteu reagent and $\mathrm{Na}_{2} \mathrm{CO}_{3}$ solution. A spectrophotometer was used to measure the absorbance of the resulting blue coloration at $560 \mathrm{~nm}$. Measurement was made with a reagent blank at zero. The phenol content was calculated using the formula below:

$$
\% \text { phenol }=\frac{100}{W} \times \frac{A u}{A s} \times C \times \frac{V t}{V a}
$$

Where $\mathrm{W}=$ weight of sample, $\mathrm{Au}=$ absorbance of test sample, As = absorbance of standard phenol sample, $\mathrm{C}=$ concentration of standard phenol sample, $\mathrm{Vt}=$ total extract volume and $\mathrm{Va}=$ volume ofextract analysed.

\section{Flavonoids}

Flavonoid content was determined using the modified method of Harborne (1973). The cookie sample $(5 \mathrm{~g})$ was refluxed for $40 \mathrm{~min}$ and allowed to cool before being filtered. The filtrate was treated with an equal volume of ethyl acetate and then transferred to a separation funnel. The flavonoid extract (contained in the ethyl acetate portion) was collected using a filter paper. The weight was obtained after drying in the oven and cooling in a dessicator. The weight was expressed as percentage of weight of sample analyzed and was calculated as shown below:

$$
\% \text { flavonoid }=\frac{W_{2}-W_{3}}{W_{1} \text { of sample }} \times 100
$$

Where $\mathrm{W}_{2}$ and $\mathrm{W}_{3}$ represent flavonoid extract in ethyl acetate portion before and after drying respectively. $\mathrm{W}_{1}$ is the initial weight of sample.

\section{DPPH (2, 2-dipheny-1-pycryl hydrazine)}

The DPPH-radical scavenging activity of the cookies sample was determined using a modified method of Blois (1958) as reported by Cakir et al. (2003). Different concentrations (0 to $350 \mu \mathrm{g}$ $\mathrm{ml}^{-1}$ ) of sample extract were pipetted into clean, dry test tubes in triplicate and the volumes adjusted to $1 \mathrm{ml}$ with $10 \mathrm{mM}$ acetate buffer, $\mathrm{pH} 4.5$. This was followed by the addition of $2 \mathrm{ml}$ of 0.2 $\mathrm{mM}$ DPPH solution in methanol. The reaction mixture was mixed thoroughly by inversion and then incubated in the dark for $30 \mathrm{~min}$. The absorbance was read at $517 \mathrm{~nm}$ against the blank that contained $1 \mathrm{ml}$ of $10 \mathrm{mM}$ acetate buffer, $\mathrm{pH} 4.5$ and $2 \mathrm{ml}$ of $0.2 \mathrm{mM} \mathrm{DPPH}$ solution in methanol. For ascorbic acid $\left(1 \mathrm{mg} \mathrm{mL} L^{-1}\right)$ and rutin $\left(1 \mathrm{mg} \mathrm{mL}^{-1}\right)$ standard, the procedure described above was followed. Scavenging activity was evaluated in percentage, using the expression:

$$
\% \text { of scavenging activity }=\frac{A c-A u}{A c} \times 100
$$

Where $\mathrm{Au}=$ absorbance of test sample, $\mathrm{Ac}=$ absorbance of the control

\subsection{Determination of anti nutrient contents of cookie samples}

\section{Tannin}

Tannin content of the sample was determined by Folin Denis colorimetric method (Kirk, Sawyer, et al., 1991). $5 \mathrm{~g}$ of the cookie was weighed and thoroughly dissolved in $10 \mathrm{ml}$ distilled water. The solution was shaken well for $30 \mathrm{~min}$ at room temperature and filtered to obtain the extract. Standard tannic solution was prepared and a 2 $\mathrm{ml}$ portion mixed with equal volume of distilled water in a separate $50 \mathrm{ml}$ volumetric flask, to serve as standard and reagent blank respectively. Then $2 \mathrm{ml}$ of each of the sample extracts were put into labeled flasks. Contents of each flask were mixed with $35 \mathrm{ml}$ of distilled water and $1 \mathrm{ml}$ of the Folin Denis reagent was added to each, followed by addition of $2.5 \mathrm{ml}$ of saturated $\mathrm{Na}_{2} \mathrm{CO}_{3}$ solution. Thereafter, each flask was diluted to the $50 \mathrm{ml}$ mark with water and incubated for 90 min at room temperature. Absorbance was read using a spectrophotometer at $760 \mathrm{~nm}$ with the reagent blank at zero. The tannin content was calculated as shown below:

$$
\text { \%tannin }=\frac{100}{W} \times \frac{A u}{A s} \times C \times \frac{V_{t}}{V_{a}}
$$


Where $\mathrm{W}=$ weight of sample, $\mathrm{Au}=$ absorbance of test sample, As = absorbance of the standard tannin solution, $\mathrm{C}=$ concentration of the standard tannin solution, $\mathrm{V}_{t}=$ total volume of extract, $\mathrm{V}_{a}=$ volume of extract analyzed.

\section{Oxalate}

The determination of oxalate content was carried out according to Day and Underwood (1986). One gram of each sample was put into separate plastic bottles followed by the addition of $75 \mathrm{ml}$ of $0.1 \mathrm{~N} \mathrm{H}_{2} \mathrm{SO}_{4}$. The content was mixed properly and allowed to extract for $1 \mathrm{~h}$ with constant agitation using a mechanical shaker. This was then filtered and $25 \mathrm{ml}$ of the filtrate was titrated with $0.1 \mathrm{ml} \mathrm{KMnO}_{4}$ while hot $\left(80-90{ }^{\circ} \mathrm{C}\right)$ until a purple colour was observed at the end point. The titre value (volume of $\mathrm{KMnO}_{4}$ used at the end point) was then multiplied by 0.9004 to get the result expressed as $\mathrm{mg} \mathrm{g}^{-1}$.

\section{Saponin}

Modified method of Fenwick and Oakenfull (1981) was used to determine saponin content of the cookies. A reflux condenser containing pure acetone was used to extract saponin for $2 \mathrm{~h}$. Exhaustive re-extraction over a heating mantle with methanol in the Soxhlet apparatus carried out for $2 \mathrm{~h}$. Methanol was allowed to evaporate and the extract was weighed. Saponin content was calculated as a percentage of the sample.

\subsection{Sensory evaluation:}

Cookie samples were evaluated for sensory attributes; appearance, taste, crispness, flavor, hardness and acceptability using thirty panellists on a hedonic scale (9-point) where 1 represented dislike extremely and 9 extremely like (Iwe, 2002).

\subsection{Statistical analysis}

All analyses were carried out in triplicate and the results were subjected to statistical analysis using Statistical Package for Social Sciences (SPSS version 21). Separation of means was carried out $(\mathrm{P} \leq 0.05)$ using the Duncan multiple range test.

\section{Results and discussion}

\subsection{Functional properties of flour blends}

Replacement of vanilla with African nutmeg had no significant effect on bulk density except for sample JLK and ranged from $0.62 \mathrm{~g} \mathrm{~cm}^{-3}$ to 0.68 $\mathrm{g} \mathrm{cm}^{-3}$. However, it significantly affected WAC $(133-142 \%)$ and OAC (147-156\%) of flour blends (Table 2). Water absorption capacity is an important functional property in the development of ready-to-eat foods, since a high WAC may assure product cohesiveness (Houssou \& Ayernor, 2002). The WAC decreased as the amount of M. myristica increased. The oil absorption capacity (OAC) is a critical assessment of flavour retention and increases the palatability of foods (Kinsella \& Melachouris, 1976). The addition of M. myristica decreased the OAC capacity of the flour blend. This could be as a result of the oil content of M. myristica (22.71-29.1\%), reported by Ekeanyanwu, Ogu, and Perpetua (2010) and Stephen et al. (2014).

\subsection{Proximate composition of formulated cookie}

The crude protein (9.44-15.49\%), crude fat (3.17-6.50 \%), total ash (1.22-2.73\%) and crude fibre $(0.12-0.23 \%)$ contents of the cookies increased (Table 3), while metabolizable energy (385.33-367 kcal) decreased (Table 4) with addition of African nutmeg. In this study, the protein content was close to the value reported by Enwereuzoh et al. (2015) in similar study. Increased protein can contribute significantly to the recommended daily intake of proteins for adults (34-56 $\mathrm{g} \mathrm{day}^{-1}$ ) and children (13-19 $\mathrm{g} \mathrm{day}^{-1}$ ) (Food and Nutrition Board, 2002). Protein is an essential nutrient in the human diet as it helps to repair worn-out tissues (Baah, 2009). Fat content of the cookie was however lower (12.96-15.21\%) than documented by Giwa and Abiodun (2010) for a biscuit produced from composite flour of wheat and quality protein maize. It is important to note 
$6 \mid$ Olatoye et al.

Table 2: Functional properties of flour blends

\begin{tabular}{lccc}
\hline Samples & Bulk density $\left(\mathrm{g} / \mathrm{cm}^{3}\right)$ & WAC $(\%)$ & OAC $(\%)$ \\
\hline KMO & $0.66^{a} \pm 0.01$ & $142^{a} \pm 0.02$ & $156^{a} \pm 0.01$ \\
JLK & $0.62^{b} \pm 0.02$ & $141^{a b} \pm 0.02$ & $155^{a} \pm 0.01$ \\
VRU & $0.67^{a} \pm 0.02$ & $139^{b} \pm 0.04$ & $152^{b} \pm 0.02$ \\
PQS & $0.68^{a} \pm 0.01$ & $135^{c} \pm 0.01$ & $151^{b} \pm 0.01$ \\
SLZ & $0.68^{a} \pm 0.02$ & $133^{d} \pm 0.01$ & $147^{c} \pm 0.01$ \\
\hline
\end{tabular}

Mean \pm standard deviation of triplicate readings, mean values followed by different

superscripts within columns were significantly different $(\mathrm{P}<0.05)$

Table 3: Proximate composition of baked cookie ( \%)

\begin{tabular}{lcccccc}
\hline Sample & Moisture & C. Protein & Crude fat & Crude ash & Crude fibre & Carbohydrate \\
\hline KMO & $6.20^{d} \pm 0.26$ & $9.44^{d} \pm 0.62$ & $3.17^{d} \pm 0.07$ & $1.22^{c} \pm 0.07$ & $0.17^{c} \pm 0.01$ & $79.80^{a} \pm 1.02$ \\
JLK & $8.33^{c} \pm 0.29$ & $12.67^{c} \pm 0.67$ & $4.27^{c} \pm 0.03$ & $1.70^{b} \pm 0.10$ & $0.12^{d} \pm 0.01$ & $72.91^{b} \pm 1.00$ \\
VRU & $8.91^{b} \pm 0.16$ & $12.96^{b c} \pm 0.80$ & $4.45^{b} \pm 0.09$ & $1.74^{b} \pm 0.10$ & $0.17^{c} \pm 0.00$ & $71.77^{b} \pm 1.14$ \\
PQS & $9.20^{b} \pm 0.96$ & $14.44^{a b} c \pm 0.95$ & $4.49^{b} \pm 0.01$ & $1.82^{b} \pm 0.07$ & $0.19^{b} \pm 0.01$ & $69.85^{c} \pm 0.89$ \\
SLZ & $13.41^{a} \pm 0.19$ & $15.49^{a} \pm 1.10$ & $6.50^{a} \pm 0.10$ & $2.73^{a} \pm 0.20$ & $0.23^{a} \pm 0.01$ & $61.64^{d} \pm 1.05$ \\
\hline
\end{tabular}

Mean \pm standard deviation of triplicate readings, mean values followed by different superscripts within columns were significantly different $(\mathrm{P}<0.05)$

that the amount of fat in a food product plays a major role in its shelf life. High fat content could be undesirable in ready-to-eat snacks as it can promote rancidity, leading to development of unpleasant sensory properties (Ihekoronye \& Ngoddy, 1985). Hence, the low fat was an added advantage with respect to the keeping quality of this cookie. Ash content (1.34-2.58\%) in this study was in agreement with reported by Eke, Achinewhu, and Sanni (2008) and was an indication of adequate mineral status of the cookie (Baah, 2009). Fibre is regarded as essential nutrient in human diet as it absorbs water and provides roughage for the bowels, assisting intestinal transit (Alaise \& Linden, 1999). The crude fibre content was low, which is however helpful to the digestive process (Alaise \& Linden, 1999). Substitution of African nutmeg for vanilla resulted in reduced carbohydrate (Table 3) and energy contents of the cookie (Table 4). This may help in the prevention of over-weight and obesity. Accurate information on energy value of foods is paramount, when it comes to the challenges of normal nutrition, under nutrition and obesity
(Merrill \& Watt, 1973).

\subsection{Physicochemical properties and colour characteristics of formulated cookie}

Substitution of African nutmeg for vanilla brought about significant $(\mathrm{p} \leq 0.05)$ reductions in $\mathrm{pH}$ (6.83-6.50) and TSS (5.80-1.20) (Table 5), with a concomitant increase in brown index (Table 6) of the cookie samples. The $\mathrm{pH}$ decreased with increased level of African nutmeg, with sample SLZ (100 \%) exhibiting lowest $\mathrm{pH}$ value, hence highest acidity. Reduction of $\mathrm{pH}$ is an indication of improved shelf stability for this snack as most spoilage micro-organisms grow best at $\mathrm{pH}$ 6.8-7.2, close to neutral (Zahra \& Safaa, 2015). Total soluble solid (TSS) followed similar trend. TSS is an indication of the amount of total soluble sugar, in particular sucrose contents of cookie samples. The control (KMO) had the highest value and SLZ (100\% African nutmeg) the least. This is a pointer to the suitability of cookie sam- 
African nutmeg and vanilla flavour blends $\mid 7$

Table 4: Physicochemical properties of baked cookie

\begin{tabular}{lcc}
\hline Samples & $\mathrm{pH}$ & TSS(Brix) \\
\hline KMO & $6.83^{a} \pm 0.12$ & 5.80 \\
JLK & $6.67^{a b} \pm 0.06$ & 5.00 \\
VRU & $6.63^{a b} \pm 0.06$ & 2.80 \\
PQS & $6.53^{b} \pm 0.20$ & 1.40 \\
SLZ & $6.50^{b} \pm 0.00$ & 1.20 \\
\hline Mean \pm standard deviation of triplicate readings, mean \\
values followed by different superscripts within columns \\
were significantly different $(\mathrm{P}<0.05)$
\end{tabular}

Table 5: Energy content of the different samples of cookie

\begin{tabular}{lc}
\hline Samples & Energy values (kcal) \\
\hline KMO & $390.62^{a} \pm 0.12$ \\
JLK & $385.48^{b} \pm 0.11$ \\
VRU & $383.63^{b} \pm 0.01$ \\
PQS & $382.18^{b} \pm 0.00$ \\
SLZ & $370.87^{c} \pm 0.01$ \\
\hline
\end{tabular}

ple SLZ in control of dietary sugar intake, especially for overweight, obese and diabetic individuals. Most spices have been associated with a bitter principle which is believed to be capable of reducing blood sugar concentrations (Uhegbu, Iweala, \& Kanu, 2011). The lightness, redness and yellowness as well as the brown index of the cookie were significantly affected by substitution of $M$. myristica. Brown index in particular increased with addition of African nutmeg (Figure 1 ). This might be attributed to the initial colour of African nutmeg and probable processing effect particularly, the baking temperature (Okafor \& Ugwu, 2014). Colour is an essential parameter in judging quality of snack foods. It reflects the suitable of raw material used for preparation and provides information about the formulation and quality of the product (Abu-Salem \& AbouArab, 2011).

\subsection{Antioxidant profile of cookie samples}

Replacement of vanilla flavour with M. myristica significantly $(\mathrm{p} \leq 0.05)$ influenced antioxi- dant characteristics among cookie samples, except flavonoids (Table 7). Sample SLZ (100 $\%$ African nutmeg) possessed highest values of total phenol and DPPH (2, 2-dipheny-2-pycryl hydrazine) contents. Similar results were documented by Stephen et al. (2014). Phenolic compounds have been reported to inhibit the activities of digestive and hydrolytic enzymes such as amylase, trypsin, chymotrypsin and lipase (Shetty, 1997). They also possess anti-carcinogenic, anti-viral, anti-microbial, antiinflammatory, hypotensive and anti-oxidant activities (Shetty, 1997). The value $0.08 \%$ obtained was slightly lower than values $(0.18 \%)$ reported by Uhegbu et al. (2011) and (0.15\%) Ndulaka, Ekaiko, Ogbonna, and Asiegbu (2016), in a similar study involving the incorporation of some spices into snacks. Flavonoids are potent water-soluble antioxidants and free radical scavengers which prevent oxidative cell damage and have strong anticancer and anti- ulcer activity (Agbaire, 2011). It might, in addition, offer protection against the different levels of carcinogenesis. 
$8 \mid$ Olatoye et al.

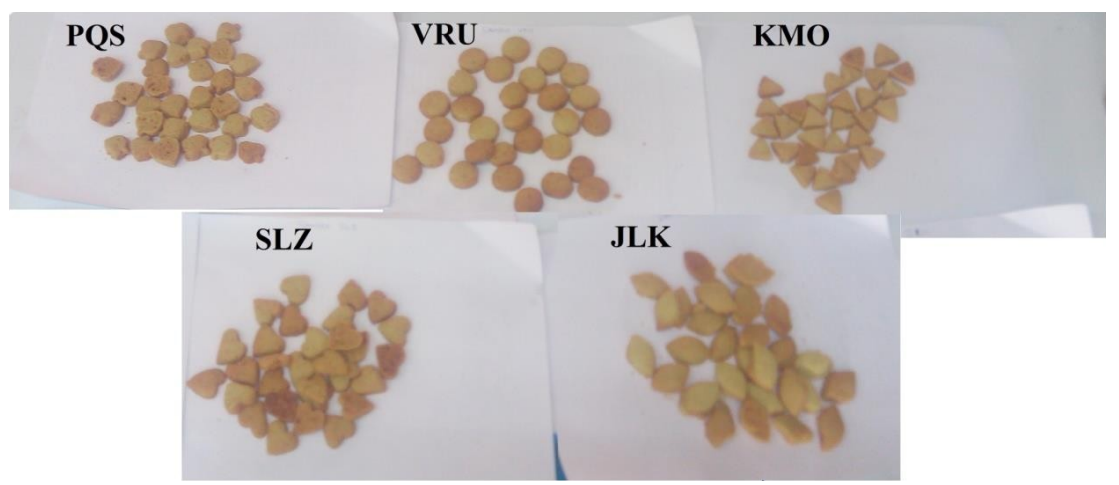

Figure 1: Cookie samples with different levels of African nutmeg as flavouring

Table 6: Colour characteristics of baked cookie samples

\begin{tabular}{lcccc}
\hline Samples & $\mathrm{L}^{*}$ & $\mathrm{a}^{*}$ & $\mathrm{~b}^{*}$ & BI \\
\hline KMO & $48.38^{a} \pm 0.29$ & $7.42^{a} \pm 0.03$ & $21.61^{a} \pm 0.05$ & $51.57^{d} \pm 0.07$ \\
JLK & $48.43^{a} \pm 0.07$ & $3.83^{d} \pm 0.02$ & $19.62^{b} \pm 0.01$ & $51.62^{d} \pm 0.03$ \\
VRU & $47.18^{b} \pm 0.04$ & $3.78^{e} \pm 0.06$ & $19.20^{c} \pm 0.03$ & $52.82^{c} \pm 0.04$ \\
PQS & $46.43^{c} \pm 0.03$ & $5.48^{c} \pm 0.06$ & $18.84^{d} \pm 0.01$ & $53.57^{b} \pm 0.03$ \\
SLZ & $42.79^{d} \pm 0.02$ & $7.29^{b} \pm 0.03$ & $18.55^{e} \pm 0.01$ & $57.21^{a} \pm 0.2$ \\
\hline
\end{tabular}

Mean \pm standard deviation of triplicate readings, mean values followed by different

superscripts within columns were significantly different $(\mathrm{P}<0.05)$

Table 7: Antioxidants profile of formulated cookie ( \%)

\begin{tabular}{lccc}
\hline Samples & Flavonoid & Phenol & DPPH \\
\hline KMO & $0.08^{a} \pm 0.004$ & $0.14^{e} \pm 0.003$ & $1.13^{c} \pm 3.9$ \\
JLK & $0.08^{a} \pm 0.01$ & $0.14^{d} \pm 0.005$ & $3.12^{b} \pm 8.8$ \\
VRU & $0.08^{a} \pm 0.007$ & $0.17^{c} \pm 0.002$ & $3.48^{b} \pm 3.8$ \\
PQS & $0.08^{a} \pm 0.002$ & $0.18^{b} \pm 0.003$ & $3.75^{b} \pm 4.5$ \\
SLZ & $0.08^{a} \pm 0.008$ & $0.24^{a} \pm 0.004$ & $5.22^{a} \pm 1.7$
\end{tabular}

Mean \pm standard deviation of triplicate readings, mean values followed by different superscripts within columns were significantly different $(\mathrm{P}<0.05)$

IJFS | October 2019 | Volume 8 | pages 1-12 
African nutmeg and vanilla flavour blends $\mid 9$

Table 8: Anti-nutritional profile of cookie ( \%)

\begin{tabular}{lccc}
\hline Samples & Saponin & Tannin & Oxalate \\
\hline KMO & $0.45^{b} \pm 0.12$ & $0.16^{c} \pm 0.02$ & $0.11^{b} \pm 0.02$ \\
JLK & $0.53^{a b} \pm 0.05$ & $0.17^{b c} \pm 0.006$ & $0.11^{b} \pm 0.02$ \\
VRU & $0.77^{a b} \pm 0.24$ & $0.17^{b c} \pm 0.008$ & $0.13^{b} \pm 0.05$ \\
PQS & $0.77^{a b} \pm 0.2$ & $0.19^{b} \pm 0.002$ & $0.15^{b} \pm 0.01$ \\
SLZ & $0.82^{a} \pm 0.21$ & $0.21^{a} \pm 0.008$ & $0.20^{a} \pm 0.00$ \\
\hline Mean \pm standard deviation of triplicate readings, mean values followed by \\
different superscripts within columns were significantly different $(\mathrm{P}<0.05)$
\end{tabular}

Table 9: Sensory evaluation scores for cookies

\begin{tabular}{lcccccc}
\hline Samples & Taste & Colour & Crispness & Flavour & Hardness & $\begin{array}{c}\text { Overall } \\
\text { acceptability }\end{array}$ \\
\hline KMO & $7.23^{a} \pm 1.61$ & $7.77^{a b} \pm 1.43$ & $7.17^{a} \pm 1.58$ & $7.37^{a} \pm 1.27$ & $7.57^{a} \pm 1.16$ & $7.63^{a} \pm 1.3$ \\
JLK & $7.67^{a} \pm 1.21$ & $8.33^{a} \pm 0.80$ & $7.60^{a} \pm 1.07$ & $7.23^{a b} \pm 1.38$ & $7.83^{a} \pm 1.34$ & $7.87^{a} \mathrm{a} \pm 1.07$ \\
VRU & $6.97^{a} \pm 1.45$ & $7.10^{b} \pm 1.75$ & $7.00^{a} \pm 1.62$ & $6.57^{b} \pm 1.59$ & $7.30^{a} \pm 1.58$ & $7.47^{a} \pm 1.25$ \\
PQS & $7.53^{a} \pm 1.07$ & $7.70^{a b} \pm 1.02$ & $7.33^{a} \pm 1.09$ & $7.10^{a b} \pm 1.4$ & $7.67^{a} \pm 1.09$ & $8.00^{a} \pm 0.91$ \\
SLZ & $7.37^{a} \pm 1.10$ & $7.30^{b} \pm 1.34$ & $7.50^{a} \pm 0.97$ & $7.40^{a} \pm 1.04$ & $7.43^{a} \pm 1.25$ & $7.80^{a} \pm 0.76$ \\
\hline
\end{tabular}

Mean \pm standard deviation of triplicate readings, mean values followed by different superscripts within columns were

were significantly different $(\mathrm{P}<0.05)$

\subsection{Anti nutritional properties of cookie samples}

The anti-nutrient content increased significantly $(\mathrm{p}<0.05)$ : saponin $(0.45-0.82 \%)$, tannin $(0.16-$ $0.21 \%)$ and oxalate (0.11-0.20\%) with substitution of M. myristica for vanilla (Table 8). African nutmeg was earlier reported to be high in phytochemicals (Ekeanyanwu et al., 2010; Stephen et al., 2014). However, the levels of these phytochemicals in this product were within the ranges earlier considered safe in humans (Ugwu \& Oranye, 2006). Health benefits of some of these phytochemicals are documented (Ugwu \& Oranye, 2006). These include reductions of pathogenesis of cancer development and damage to intestinal tract (Makkar \& Becker, 1996; Ugwu \& Oranye, 2006). The low levels of tannin content in the cookie samples corresponded to the values reported by Uhegbu et al. (2011) and (Ndulaka et al., 2016).

\subsection{Sensory attributes of formulated cookie}

There was no significant difference $(\mathrm{p}<0.05)$ between the mean sensory scores for most attributes of cookie samples and control, except in colour and flavour (Table 9). Cookie samples increased in brownness with increased levels of M. myristica, which may be due to the colour of the nutmeg powder. Similar trend was observed for flavour, which is the main criteria that makes the product to be liked or disliked (AbuSalem \& Abou-Arab, 2011). The assessment of flavour was done by the combination of taste and smell. Sample SLZ (100\% African nutmeg) was adjudged the most acceptable in terms of flavour by the panelists. The overall acceptability of the samples was based on their (panelist) individual performance on evaluation. Iwe (2002) considered a product with overall acceptability score of 7.0 as being accepted by consumer. It was observed that all samples were generally accepted by panellists, but SLZ (sample with $3.5 \mathrm{~g}$ of $M$.

IJFS | October 2019 | Volume $8 \mid$ pages 1-12 
myristica and $0 \mathrm{~g}$ of vanilla flavour) being the most acceptable.

\section{Conclusions}

Cookies of good nutritional standard and acceptable sensory qualities were produced from replacement of vanilla flavour with African nutmeg in the formulation. Functional properties of the flour blends were not affected markedly as a result of $M$. myristica seed flour substitution for vanilla flavour. Increased addition of $M$. myristica significantly influenced the proximate composition, physicochemical properties, phytochemical content and antioxidative potential of the cookies at the $95 \%$ confidence level. The cookies compared very well with the control in virtually all the sensory attributes with sample SLZ (100\% replacement) being the most acceptable to the panellists. M. myristica seed could serve as a flavourant in the production of cookies and similar snacks and the replacement of vanilla flavour with African nutmeg is potentially possible. Studies on microbial characteristics and storage stability of such products are important and therefore recommended.

\section{References}

Abu-Salem, F. M., \& Abou-Arab, A. A. (2011). Effect of supplementation of bambara groundnut (Vigna subterranean 1.) flour on the quality of biscuits. African Journal of Food Science, 5(7), 376-383.

Adeboye, A. S., Babajide, J. M., Shittu, T. A., Omemu, A. M., \& Oluwatola, O. J. (2013). Effect of honey as partial sugar substitute on pasting properties, consumer preference and shelf stability of cassava-wheat composite bread. Nigerian Food Journal, 31 (1), 13-22. doi:10.1016/S0189-7241(15)30051-5

Agbaire, P. O. (2011). Nutritional and antinutritional levels of some local vegetables (vernomia anydalira, manihot esculenta, teiferia occidentalis, talinum triangulare, amaranthus spinosus) from delta state, nigeria. Journal of Applied Sciences and Environmental Management, 15(4), 625628.
Ajieroh, V. (2010). A Quantitative Analysis of Determinants of Child and Maternal Malnutrition in Nigeria. IFPRI Nigeria Strategy Support Program, Brief No. 11.

Aladesanmi, A. J. (2007). Tetrapleura tetraptera: Molluscicidal activity and chemical constituents. African Journal of Traditional Complementary and Alternative Medicines, 4(1), 23-36.

Alaise, C., \& Linden, G. (1999). Food biochemistry. (pp. 15-121). Chapman and Hall, Food Science Book. Aspen Publishers Inc. Maryland.

AOAC. (1990). Official Methods of Analysis; Association of Official Analytical Chemists 15th ed., Washington D.C. USA.

AOAC. (1995). Official methods of Analysis, 15th edition, Vol.2.Association of official Chemists. Arlington, Virginia.

AOAC. (2000). Association of Official Analytical Chemists, 17th Edition, The Association of Official Analytical Chemists, Gaithersburg, MD, USA.

Baah, F. D. (2009). Characterization of water yam (dioscorea alata) for existing and potential food products (Doctoral dissertation, Faculty of Biosciences College of sciences kwame Nkrumah University of Science and Technology, Kumasi Ghana).

Babajide, J. M., \& Odulate, D. T. (2015). Varietal influence on the functional properties of yam starch. Book of Extended $a b$ stracts of the 39th Nigerian Institute of Food Technology Annual Conference and General Meeting, Oweri, 271-272.

Blois, M. S. (1958). Antioxidant determination by use of stable free radicals. Nature, 29, 1199-1200.

Burubai, W., Akor, A. J., Igoni, A. H., \& Puyate, Y. T. (2007). Effects of temperature and moisture content on the strength properties of African nutmeg (Monodora myristica). International Agrophysics, 21(3), 217-223.

Cakir, A., Mavi, A., Yildirim, A., Duru, M. E., Harmandar, H., \& Kazaz, C. (2003). Isolation and characterization of antioxidant phenolic compounds from the aerial parts of hypericum hyssopifolium 1. by activity-guided fractionation. Journal of Ethnopharmacology, 87(1), 73-83. 
Day, R. A., \& Underwood, A. L. (1986). Qualification analysis 5th, 103-105.

Eke, J., Achinewhu, S. C., \& Sanni, L. (2008). Nutritional and sensory qualities of some nigerian cakes. Nigerian Food Journal, $26(2)$.

Ekeanyanwu, C., Ogu, G., \& Perpetua, N. (2010). Biochemical characteristics of the african nutmeg, monodora myristica. Agricultural Journal, 5, 303-308. doi:10.3923/ aj.2010.303.308

Eneche, E. H. (1999). Biscuit-making potential of millet/pigeon pea flour blends. Plant foods for human nutrition, 54, 21-7. doi:10.1023/ A:1008031618117

Enwereuzoh, R. O., Damaris Chinwendu, O., Uzoukwu, Ukanwoke, Nwakaudu, \& N. Uyanwa, C. (2015). Flavour extraction from monodora myristica and tetrapleura tetraptera and production of flavoured popcorn from the extract. European Journal of Food Science and Technology, 3(2), 1-17. doi:10.13140/RG.2.2.14061.90087

Essien, E. U., Izunwane, B. C., Aremu, C. Y., \& Eka, O. U. (1994). Significance for humans of the nutrient contents of the dry fruit oftetrapleura tetraptera. Plant Foods for Human Nutrition, 45(1), 47-51. doi:10. 1007/BF01091228

FAO. (2011). Food and Agricultural Organization of the United Nations Foods Outlook, Global Market Analysis, published by the Trade and market division of FAO under Global Information and Early Warning System (GIEWS), November, Pp.39.

Fenwick, D. E., \& Oakenfull, D. (1981). Saponin content of soya beans and some commercial soya bean products. Journal of the Science of Food and Agriculture, 32(3), 273-278.

Food and Nutrition Board. (2002). Dietary reference intake for energy, carbohydrate, fiber, fatty acids, cholesterol, protein and amino acids. Food and Nutrition Board, Institute of Medicine. National Academy Press. (KH) Washington, D. C. 422-541.

Giwa, E. O., \& Abiodun, V. (2010). Quality characteristics of biscuits produced from composite flours of wheat and quality protein maize. African Journal of Food Science and Technology, 1(5), 116-19.
Harborne, J. B. (1973). Phytochemical methods. doi:10.1007/978-94-009-5921-7

Houssou, P., \& Ayernor, G. S. (2002). Appropriate processing and food functional properties of maize flour. African Journal of Science and Technology, 3(1).

Ihekoronye, A. I., \& Ngoddy, P. O. (1985). Integrated food science and technology for the tropics. Macmillan.

Iwe, M. O. (2002). Handbook of sensory methods and analysis. Rojoint Communication Services Ltd., Enugu, Nigeria, 7-12.

Kinsella, J. E., \& Melachouris, N. (1976). Functional properties of proteins in foods: A survey. Critical Reviews in Food Science 83 Nutrition, 7(3), 219-280.

Kirk, S., Sawyer, R. et al. (1991). Pearson's composition and analysis of foods. Longman Group Ltd.

Kruger, A. (2012). Demographics, purchasing behaviours and nutrient composition among vending machine consumers at the ohio state university. Retrieved from http://hdl. handle.net/1811/51914

Maclean, W., Harnly, J., Chen, J., ChevassusAgnes, S., Gilani, G., Livesey, G., \& Warwick, P. (2003). Food energy-methods of analysis and conversion factors. In Food and agriculture organization of the united nations technical workshop report (Vol. 77). Retrieved from http: / / www . fao.org / docrep / 006 / Y5022E / y5022e00.htmhttp: / / www . fao . org / uploads / media / FAO_ 2003_Food_Energy_02.pdf

Makkar, H., \& Becker, K. (1996). Nutrional value and antinutritional components of whole and ethanol extracted moringa oleifera leaves. Animal Feed Science and Technology-ANIM FEED SCI TECH, 63, 211-228. doi:10 . 1016 / S0377 - 8401(96 ) 01023-1

Merrill, A. L., \& Watt, B. K. (1973). Energy value of foods: Basis and derivation (agriculture handbook no. 74). Washington: US government printing office.

Ndulaka, J. C., Ekaiko, M. U., Ogbonna, C. R., \& Asiegbu, E. I. (2016). A comparatives study on the nutritional and antinutritional values of the seeds of piper guineense, monodora myristica and oci- 
mum gratissimum as popular spices used in south eastern nigeria. Journal of Biological Sciences, 4 (1).

Norfezah, M. N. (2013). Development of expanded snack foods containing pumpkin flour and corn grits using extrusion technology. Thesis presented in partial fulfilment of the requirement for the degree of $\mathrm{PhD}$, Massey University, Palmerston North, New Zealand.

Okafor, G. I., \& Ugwu, F. C. (2014). Production and evaluation of cold extruded and baked read-to-eat snacks from blends of breadfruit (treculiaafricana), cashewnut (anacardiumoccidentale) and coconut (cocosnucifera). Food Science and Quality Management, 23, 65-77.

Olatoye, K., \& I. Lawal, A. (2016). Storability of " dodoikire " (over -ripe plantain-basedsnack) at ambient temperature $\left(28 \pm 2^{\mathrm{O}}\right.$ c). Agricultural Engineering International : The CIGR e-journal, 18.

Sajilata, M. G., \& S. Singhal, R. (2005). Specialty starches for snack foods. Carbohydrate Polymers, 59, 131-151. doi:10.1016/ j.carbpol.2004.08.012

Shetty, K. (1997). Biotechnology to harness the benefits of dietary phenolics: Focus on lamiaceae. Asia Pacific journal of clinical nutrition, 6, 162-71.

Sosulski, F. W. (1962). The centrifuge method for determining flour absorption in hard red spring wheats. Cereal Chemistry, 39, 344-350.

Stephen, A. E., O., F., Oboh, J., \& Eseosa, O. U. (2014). Antimicrobial, Nutritional and Phytochemical Properties of Monodora myristica Seeds. IOSR Journal of Pharmacy and Biological Sciences, 9(4), 01-06.

Sumargo, F. (2016). Improving the utilization of dry edible beans in a ready-to-eat snack product by extrusion cooking. Dissertations and Thesis in Food Science and Technology. Paper 67. Retrieved from htp:// digitalcommons.unl.edu/foodscidiss / 67

Ugwu, F. M., \& Oranye, N. A. (2006). Effects of some processing methods on the toxic components of african breadfruit (treculia africana). African Journal of Biotechnology, $5(22)$.
Uhegbu, F., Iweala, E., \& Kanu, I. (2011). Studies on the chemical and antinutritional content of some nigerian spices. International Journal of Nutrition and Metabolism, 3.

Zahra, S. A., \& Safaa, S. A. (2015). Functional and antioxidant properties of novel snack crackers incorporated with hibiscus sabdariffa by-product. Journal of Advanced Research, 6(1), 79-87. Drug discovery. doi:10. 1016/j.jare.2014.07.002 